Scholedge International Journal of

Multidisciplinary \& Applied Studies

ISSN 2394-336X, Vol.05, Issue 03 (2018)

Pg 27-36.

DOI: 10.19085/journal.sijmas050301
Published by: Scholedge Publishing www.theSCHOLEDGE.org

Email: editorial@thescholedge.org

(C) Publisher

\title{
Economic Environment and Entrepreneurial Development in Lagos and Ogun States, Nigeria
}

\author{
OLABISI Jayeola \\ Department of Accounting,College of Management Sciences,Federal University of Agriculture, \\ Abeokuta,Ogun State, Nigeria \\ OLADUNJOYE, T. OLAWALE \\ Centre for Entrepreneurship Development, Yaba College of Technology, Yaba, Lagos
}

ADEWUMI, A. A.

Department of Accounting, College of Management Sciences,Federal University of Agriculture, Abeokuta, Ogun State, Nigeria

\begin{abstract}
The study empirically examines the relationship that exists between economic environment and entrepreneurial development in Nigeria. A structured questionnaire is administered on the study and data collected are analysed using Analysis of Variance and Regression. The following variables are indices of determination; Interest Rate (IR); Income Tax (IT).The results of the study show that there is a significant relationship between IR and ED in Nigeria $(\mathrm{p}<0.5)$ with a positive correlation $\left(r=0.526, \mathrm{r}^{2}=0.276\right)$. Also, there is a significant relationship between IT and ED in Nigeria $(p<0.05)$, with a positive association $\left(r=0.546 ; r^{2}=0.299\right)$. The study concludes that, the emergence of higher level of stable economic environment is critical to entrepreneurial development in Nigeria. Therefore, government involvement in public private partnership for infrastructural development, enlargement of productive, judicious and transparent use of funds collected from income tax and affordable interest rate will galvanise the inward sourcing of raw materials that boost entrepreneurial development in Nigeria.
\end{abstract}

Key-words: interest rate, income tax, business environment and entrepreneurial development

\section{INTRODUTION}

Economic growth in most developing countries, including Nigeria, is either stunted or slow due to preponderance of several environmental factors of which one is inadequate infrastructure (Glover, 2012). Similarly, evidence has also shown that the poverty level is high as the rate of unemployment continues to rise (Ajayi, 2010). In order to tackle the problems of unemployment and poverty, economic policy makers have recommended the promotion of entrepreneurial development as a socio-economic panacea (Asikhia, 2009; Asikhia, 2013). But entrepreneurial development is a phenomenon which operates in a complex business environment in Nigeria. Macroeconomic or environmental variables which feature significantly in the business environment greatly influences the operations of business have impacted negatively on business decision-making process (Dwivedi, 2007). Complications in economic activities and the complexity in the relationships between micro and macroeconomic variables dictate the application of theories which facilitate understanding of the interplay of variables within the business environment. Entrepreneurial development is an embodiment of the process of enhancing entrepreneurial skills and knowledge through structured training and institution building programme, focusing on the individual who desires to start or expand a business (Osemeke, 2012).

A vibrant entrepreneurial climate provides new jobs, increases competitiveness, and produces novel goods and services (Glover, 2012). Therefore, it is good for policymakers to increase entrepreneurial activities through various means. However, the influence of economic environment on entrepreneurial development is inconclusive (Bruce, 2000; Chen and Ravallion, 2008; Feldman and Bolino, 2000; Porter and Schwab, 2008). Business is a product of the environment and its continued survival depends on how well it is integrated into the society to meet people's needs in

http://dx.doi.org/10.19085/journal.sijmas050301 
line with perception. Economic environment is an aggregation of factors that affect the operations, cost, benefits, growth, development and survival of enterprises (Okwu, 2012). Elements of economic environment include extent and quality of infrastructural provision, interest rate and income tax rates prevailing in the economy at a particular time (Iyanda, 1988). Economic environment is considered as the interrelated and interdependent variables or forces that affect the ways business operate (Okafor and Monde,2010). Hence, this study seeks to assess the extent of influence economic environment has on entrepreneurial development in Lagos and Ogun States, Nigeria.

In other to achieve the objective of the study, following the background is section 2 that dealt with the review of related literature, while section 3 concerned methodology and results of analysis while Section 4 presented findings from the study and drew conclusion.

\section{STATEMENT OF THE PROBLEM}

Weak and inadequate infrastructure impacts severely on economic growth and human capital development in Nigeria (Ajayi, 2010). The current level of infrastructure deficit in the country is perhaps the major constraint against Nigeria's efforts at achieving the nation's vision of becoming one of the 20 largest economies by 2020 (Bello, 2012). World Bank (2006) reports show that approximately 70 percent of the $193,000 \mathrm{~km}$ of roads in the country is in poor condition while only 20 percent are tarred. The country experiences an average of over 100 losses of industrial activities on a daily basis due to the poor economic environment such as high interest rate, multiple taxations coupled with power outage with over 60 percent of population having no access to electricity (Gboyega, 2013). Since deregulation of interest rates in the 1980s, every successive government in Nigeria has been contending with fluctuating interest rates in spite of efforts made to address the problem. Okonjo-Iweala (2003) admits that the current regime of interest rates in Nigeria is too high for the productive sector of the economy. World Bank (2006)averts that monetary policy has kept monetary policy rate at 12 percent. This determines the direction of interest rate in the Nigerian economy but, many Nigerian banks charge lending rate above 20 percent which is described as too high (Sokefun 2013). Consequently, local investors experience difficulty with the current rates of interest. Hence, this development discourages existing and prospective entrepreneurs from approaching banks for loans.

The global average income tax shows that Nigeria still has one of the highest income tax rates in the world (Bello, 2012). The investment climate in Nigeria is characterized by a regime of multiple taxes imposed by different tiers of government, unpredictability, high operational costs and bureaucratic bottleneck among others (Ashogbon, and Ejike, 2008). The issue of multiple taxes has been of economic concern to manufacturers in Nigeria for several years. Despite several attempts by the succeeding government to tackle it, it has remained unabated affecting the free conduct of business and movement of goods and services. This is particularly harmful to the economy as it increases the cost of doing business in Nigeria. Given the inconclusive and inconsistent results of previous studies as to the extent of influence income tax has on entrepreneurial development, this study seeks to examine the relationship that exists between income tax and entrepreneurial development in Lagos and Ogun States, Nigeria.

From the above background, there are various empirical studies on economic environment and entrepreneurial development in developed countries like those of (Ashogbon, and Ejike, 2008) and (Osemeke 2012). But relative few in developing economies like Nigeria. Hence, the thrust of this study is to evaluate and bridge the gap in literature between Economic environment and entrepreneurial development in developing economies, specifically Nigeria.

\section{Objective of the Study}

The broad objective of the study is to assess the relationship that exists between economic environment and entrepreneurial development in Lagos and Ogun States, Nigeria. The specific objectives are to:

I. investigate the relationship that exists between interest rate and entrepreneurial development in Lagos and Ogun States, Nigeria; and

II. analyze the relationship that exists between income tax and entrepreneurial development in in Lagos and Ogun States, Nigeria

\subsection{LITERATURE REVIEW}

\subsection{Factors influencing entrepreneurial activity}

http://dx.doi.org/10.19085/journal.sijmas050301 
A number of factors have been identified in the research literatures that influence the level of entrepreneurial activity in a country or region, some of which are dominance of the public sector, existence of strict labour laws; high nonwage labour costs and negative attitude of the population towards entrepreneurship are conceived (Audretsch and Thurik, 2000). Factors such as population and growth density of small businesses and positive attitudes towards entrepreneurship have positive effect on the level of activity (Fristsch 2008). It is observed that countries with the large public sectors relative to the private sector and strict labour laws tend to have lower levels of business ownership and countries with a higher density of business owners per capita and high population growth tend to have higher levels of entrepreneurial activity (World Bank 2006).In the early 1990s the focus on entrepreneurial development was often driven by economic adversity, high unemployment, downsizing of large corporations and government deficits. The situation has now stabilized, but there is growing recognition that dynamism, innovation and entrepreneurship are central elements in the transition from a managed economy to an entrepreneurial economy (Audretsch and Thurik, 2000). There are disincentives which hinder people from considering setting up their own businesses while others limit opportunity such as government providing many services; high tax wedge leaving little room for personal services or businesses. Rigid labour market policies, complex employment legislation and administrative burden, constitute actual barriers to business entry and also influence an individual's decision on whether to start a business coupled with the ease with which such individuals are able to operate business (Okwu 2012).

Other factors that influence entrepreneurial activity positively include population growth, growing population leads to increased demand for products and services and increase the base for new business opportunities. Lehmann, Parmentier and Van der Linden (2009) and Fristsch (2008) assert that growth in per capita GDP or higher standard of living leads to increased prosperity and opportunities. Also, higher income increases disposable income which translates to effective demand that promotes business start-up. Thurik (2009) submits that higher income dispersion may provide the accumulated savings required for investment in new firms. Higher income individuals and households may create demand for goods and services that provide opportunities for new firms; demand is the mother of invention. If there is weak demand for goods and services people will not be lured to embark on new ventures. Positive attitudes towards entrepreneurship lead to positive intent to start a business (Naude, 2008). Societies that value self-sufficiency, individualism and self-reliance are more predisposed to entrepreneurship. Similarly, exposure to role model has a demonstration effect on others while recognition of role models serves to increase social legitimacy of entrepreneurship. The more exposed to entrepreneurial activities can individual may be, the higher the propensity to become an entrepreneur. This is impacted by growing up in an environment of entrepreneurial activities knowing other entrepreneurs from personal and business network and being engaged in apprenticeship in small firms. Exposure to entrepreneurship through education is another potent factor. Higher levels of education correlate with higher levels of entrepreneurial activity. Students of entrepreneurship at all levels of the education system, across disciplines, can play a key role in fostering entrepreneurship, graduate students should be provided with several opportunities to learn entrepreneurial skills and gain experience through exposure. Ease-ofdoing business is another factor to consider, excessive regulation and high compliance costs in the registration of a new business can act as impediment to entrepreneurship (Lehmann, Parmentier and Van der Linden, 2009). In order to encourage start up business incorporation laws need to be relaxed. There should be reduction in start-up procedures and compliance costs, government should simplify licensing and permits requirements, and all these should be accomplished within shorter time (Okwu, 2012).

Higher levels of entrepreneurial activity can be stimulated within economically disadvantaged and minority groups and economically disadvantaged regions. Targeting entrepreneurship policy measures at groups of the population under-represented as business owners, including entrepreneurship development as part of regional development policy. Policy should encourage women to become entrepreneurs, countries with the highest level of business ownership by women also have higher levels of entrepreneurial activity, increase participation of women as entrepreneurs will contribute to economic growth (Thurik 2009). This could be achieved by involving women in loans programs, mentoring, networking exposure and training. Positive, supportive climate and infrastructure for entrepreneurship at the regional level is germane. Entrepreneurship activity levels are highest in regions that provide lots of support for new and growth-oriented entrepreneurs. These infrastructure include business support programs and services oriented to new entrepreneurs which may include incubators, web-portals, advisory services, one-step shop; mentoring, networking identify and encourage regional growth companies. Most government departments are not well-versed in the needs of entrepreneurs and small firms. These act as barrier to good governance in the interest of the small business sector. This can be ameliorated by establishing a private-sector entrepreneurship advocacy organization within government to develop better understanding of their need within other government departments 
and regulators. Well-functioning, decentralized market economy is advocated open markets offer potential for new business entries (Lehmann, Parmentier and Van der Linden (2009). An oversized public service distorts competition. Deregulation of industry sectors, privatization of government enterprises and review of competition policy will lure new firms and encourage the creation of new firms. As a major buyer of products and services, government is a possible lucrative market for new firms; government should draft procurement policies that make it possible for new small firms to compete for government contracts. High levels of social security can act as a disincentive to the decision to become an entrepreneur (Tily, 2010). Government can provide incentives for under and unemployed individuals to start business. A person's perception of the costs of business failure can act as a disincentive to entrepreneurship. Higher tax rates on self-employment income act as a disincentive to individual's decision to leave paid employment to start a business. So also, taxation of business at the higher tax rate reduces valuable cash flow for reinvestment business. More so, high capital gains tax poses a threat to investors in high growth firms and, it is an obvious barrier to the continuity of enterprises. These tax issues can be ameliorated through different tax reforms, which include tax relief for new starters, reduction of corporate tax rates on first tier of business profits, offering of start-up tax allowances, exemptions and general reduction of capital gains tax, inheritance and estate taxes. The literature on banks' interest rate setting behaviour generally assumes that banks operate under oligopolistic market conditions. This means that a bank does not act as price-taker but sets its loan rates taking into account the demand for loans and deposits. Better economic conditions improve the number of projects becoming profitable in terms of expected net present value and, therefore, increase credit demand (Kashyap, Stein and Wilcox, 1993). As stressed by Melitz and Pardue (1973) only increases in permanent income have a positive influence on loan demand, while the effect due to the transitory part could also be associated with a selffinancing effect that reduces the proportion of bank debt (Friedman and Kuttner, 1993). An increase in the money market rate raises the opportunity cost of other forms of financing, making lending more attractive. A higher level of income increases the demand for deposits and reduces incentive for banks to set higher deposit rates and the shift of deposit demand should be higher if the transitory component of GDP is affected. On the contrary, an increase in the money market rate, ceteris paribus, makes more attractive to invest in risk-free securities that represent an alternative to detain deposits; the subsequent reduction in deposits demand determines an upward pressure on the interest rate on deposits.

\subsection{Interest Rate and Entrepreneurial Development}

The cost of borrowing money, measured in naira, per year per naira, borrowed, is the interest rate. Interest rates differ mainly in maturity that is the length of time for repayment and liquidity that is quick conversion of assets to funds. When maturity and liquidity together with other factors are considered, many different financial instruments and so many different interest rates will emerge (Anyanwu, 1998). Interest rates can either be nominal or real. Nominal interest rate can be measured in naira terms, not in terms of goods. The nominal interest rate measures the yield in naira per year, per naira invested while the real interest rate is corrected for inflation and is calculated as the nominal interest rate minus the rate of inflation (Audretsch, and Keilbach, 2004). The major constraint to entrepreneurship development across the globe is the dearth of investible funds, especially in less developed countries where entrepreneurship is believed to be the only magic wand for economic prosperity, inadequacy of investible fund and the high cost of available ones are quite detrimental to the survival of business. The relationship between interest rate (cost capital) is easily captured by the marginal efficiency of investment schedule which shows as inverse relationship between interest rate and investment, thus increase in the cost of capital leads to a decline in investment all other things being equal. Investment is defined as entrepreneurial development, and then it follows that increase in the cost of capital leads to a decline in entrepreneurial development ceteris paribus. The classical theory of interest rate supports this argument (Anyanwu, 1998). According to this class of theorists, interest rate is determined by demand and supply of capital by businessmen and household. Accordingly, the supply of capital is governed by the time preference and the demand for capital by the expected productivity of capital; Thus the higher the demand for capital by these economic agents (business-people and household), the higher the cost of lending (Anyanwu 1998).

Another explanation to causes of variation or volatility in interest rate is the Loanable Fund Theory of interest propounded by (Tily, 2010). Theory postulates that the existing lending rate is a function of the interaction of demand for and supply of loanable funds or credit. The explanation linking interest rate with low investment and hoarding of funds sourced from government, businessmen and consumers on the demand side with saving, dishoarding and bank money on the supply side from private individuals and corporate bodies. By implication, a high interest rate results when low hoarding and investment is greater than saving, dis-hoarding and bank money.

http://dx.doi.org/10.19085/journal.sijmas050301 
Keynes liquidity preference theory is another explanation to interest rate determination. The theory links interest rate to demand for and supply of money. It emphasizes that the rate of interest is a purely monetary phenomenon as distinct from the real theory of the classics (Basile, John and Hugh, 2011). In other words, the theory argues that increase in the volume of the money with the commercial bank has a decreasing effect on interest rate will fall on the other way round. The theory holds very strong policy implication for interest rate. Most economies in recent times induce the level of business activities through interest rate management, guided the overall monetary policy (Turner, 2011). Deduction from the various explanations of the relationship between interest Rate and entrepreneurship development is indicative that high interest rate (cost of capital) affects the existing businesses and even deters new entrants. In the policy framework, interest rate determination for entrepreneurship becomes interesting since a poor policy will crowd-out entrepreneurship. The study has examined Neo-classical, classical, psychological, sociological and anthropological entrepreneurial theories. But largely, Schumpeter's theory was adopted as basis for entrepreneurial development in this study.

\subsection{Taxsystem and Entrepreneurial Development}

Several explanations on the relationship between taxation and entrepreneurship exist like those of (Enahoro and Olabisi 2012) and (Audretsch, and Keilbach, 2004). Some of these explanations showed that government specific policies toward entrepreneurship especially the tax system can potentially have positive and negative effects on entrepreneurship. Some tax policies, such as accelerated capital recovery for small businesses, target entrepreneurs, but other tax effects may arise from general tax policy choices, such as the choice of the shape of the tax rate schedule. Considering the riskiness of entrepreneurship the argument is that the shape of tax schedule may play an important role in affecting entrepreneurial decisions because, with a progressive income, successful ventures may face a higher tax rate than unsuccessful ventures face. Tax policy can affect entrepreneurship and innovation through various channels. Broadly speaking, these channels can be categorized as the effects of general tax policies (change in marginal tax rates) and targeted tax policies (such as a tax credit for research). In assessing how general tax policies affect entrepreneurship, the critical question is: Why would the tax policy have a differential effect on entrepreneurship relative to other economic activity? For targeted tax policies, the policy design question is: Can the policy encourage the desired behaviour without providing subsidies to projects that would have taken place without the targeted policy? One common hypothesis regarding the differential effects of tax rates on self-employment (one measure of entrepreneurship) and working for someone else is that higher tax rates encourage self-employment because it provides tax-sheltering opportunities. These tax-sheltering opportunities include both tax evasion (it is relatively easy to underreport self-employment income) and tax avoidance (legal opportunities to deduct businessrelated consumption from one's taxable income). The value of these tax-sheltering opportunities increases with the tax rate, which leads to the hypothesis that higher tax rates increase the level of self-employment in the economy. The tax-sheltering hypothesis provides one channel for general tax policies to affect the decision to be an entrepreneur. Imperfect loss-offset provisions provide another example of how relatively risky projects face a higher tax burden than relatively safe projects face. Rather than focusing on the riskiness of occupational choices, the analysis of loss-offset provisions usually focuses on corporate investment.

Enahoro and Olabisi (2012) examined the overall effectiveness of tax administration in relation to assessment, collection and remittance of tax in Lagos State Nigeria using Kendall measure. Their findings confirm that tax administration affects the revenue generated by Lagos government; also there is a significant relationship between tax administration, tax policies and tax laws which impact on entrepreneurial development in the state. It was also discovered that tax payer avoid and evade tax as a result of the corrupt practices of tax officials, this also reduces the fund made available to the government to provide infrastructure and other services needed to promote entrepreneurship. Enahoro, Olabisi and Dafe (2013) discovered from their study that there is no single appropriate tax system for any developing country that can be plucked off the shelf and implemented without taking into consideration tax policies, laws and administration. The trust of the study is that neglecting the entrepreneur in theories of taxation has resulted in misleading policy implications. Indeed, issues of secondary importance in the analysis of large, established firms may be crucial when analyzing small entrepreneurial businesses.

For corporations, reporting negative taxable income does not necessarily generate a tax refund. Instead, corporations benefit from losses in one year by applying a set of tax-loss carry-back and carry-forward rules; these rules specify a limited time period over which corporations can essentially average their income (Ukpon, 2012). These rules create another form of success tax in the tax code, whereby successful firms face a higher tax rate than unsuccessful firms face. In the extreme, if a corporation has negative taxable income in a year but does not have sufficient positive 
income during the carry-back or carry-forward period, then it faces a tax rate of zero on the losses; however, had the corporation been successful, it might face the top corporate tax rate of 35 percent (Altshuler and Alan 1990). Another channel for general tax policies to affect entrepreneurship arises because entrepreneurship is riskier than other occupational choices and because innovative investments are riskier than other possible investments. Thus, tax policies that affect the returns from taking risks can have consequences for entrepreneurship. Because the returns from entrepreneurship are relatively risky, the level of the marginal tax rate is unlikely to capture the complete effect of tax policy on entrepreneurship (Cullen and Gordon 2002; Gentry and Hubbard, 2003).When investment is risky, the tax effects may depend on the overall shape of tax schedule, which is not captured by a local measure of the marginal tax rate. Capital gains tax provides a final channel through which general tax policy can affect entrepreneurship and if entrepreneurial activity inherently generates more of its income as capital gains relative to other employment or investment choices, then lower capital gains tax rates may increase entrepreneurial activity (Okwu 2012). These capital gains tax effects are often discussed in the context of the taxation of venture capital (Porter and Schwal, 2008).

Given the importance of entrepreneurship to the overall economy, the effects on entrepreneurship could be an important part of the overall effects of tax policy, especially if the effects on entrepreneurship are large. In contrast to the effects of general tax policies on entrepreneurship, specific tax policies can be targeted at small businesses and innovation. Such targeted tax policies include tax credits for research and development; favourable depreciation rules for the capital expenditures of small businesses; reduced capital gains taxes after the initial public offer of qualified small-business stock; and preferential exemptions for business assets under the estate tax. The goals of these policies are aimed at promoting specific aspects of entrepreneurship or solving problems associated with taxing small businesses. For small businesses, Slemrod (2003) argues that these tax preferences may offset the high tax compliance costs relative to business size that small businesses face.

\section{METHODOLOGY}

The study employed descriptor-explanatory survey design in which the study population was 5,953 small and medium enterprises in Lagos and Ogun States. NIHR Research Design Survey was adopted to arrive at a sample size of 1,220 and a total of 730 respondents representing approximately $60 \%$ response rate were properly filled, returned and analyzed. A structured questionnaire was constructed, validated and administered to entrepreneurs in Lagos and Ogun States. The reliability test of the instrument showed a Cronbach Alpha value of 0.83. Descriptive statistics, multiple regression statistics and Pearson's Product Moment Correlation Coefficient were employed to

analyse the data. The independent variables economic environment proxies were Interest Rate (IR) and Income Tax (IT) while the dependent variable is Entrepreneurial Development (ED).

Operationalization of variables $\mathrm{X}=$ Independent variable

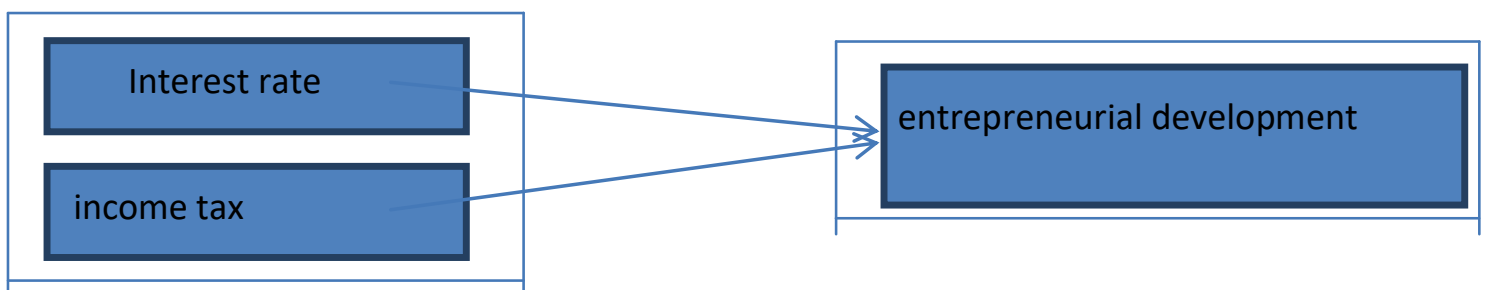

Source: Researcher's conceptual model 2017

Ho: There is no significant relationship between income tax and entrepreneurial development in Lagos and Ogun states Nigeria.

$\mathbf{H}_{\mathbf{0}}$ : There is no significant relationship between interest rate and entrepreneurial development in Lagos and Ogun states, Nigeria.

Hypothesis one depicts significant relationship between income tax rate and entrepreneurial development. From the model summary table, the correlation coefficient $(\mathrm{R})$ value is $.546^{*}$ which implies that there is a strong positive linear association between income tax and entrepreneurial development in Lagos and Ogun states, Nigeria. With reference to the model summary table, it is observed that the coefficient of determination is 0.299 which means that 
about $29.2 \%$ of entrepreneurial development in the states is explained by income tax, while other factors not under investigation responsible for about $70.8 \%$.

Table 3.1 Model summary

\begin{tabular}{|l|l|l|l|l|}
\hline Model & R & R Square & Adjusted R Square & Std. Error of the Estimate \\
\hline 1 & $.546^{\mathrm{a}}$ & .299 & .292 & .644 \\
\hline
\end{tabular}

Predictor: (constant) income tax

Source: Researchers' computation (2014)

Since the $\mathrm{P}$ value (.000) is less than the specified level of significance .05 the null hypothesis is therefore rejected and conclude that there is a significant statically relationship between income tax and entrepreneurial development in Lagos and Ogun states, Nigeria.

Table: $3.2 \quad$ ANOVA

\begin{tabular}{|ll|l|l|l|l|l|}
\hline Model & & Sum of Squares & Df & Mean Square & f & Sig. \\
\hline \multirow{4}{*}{1} & Regression & 119.814 & 6 & 19.969 & 48.162 & $.000^{\mathrm{b}}$ \\
& Residual & 281.527 & 679 & .415 & & \\
& Total & 401.341 & 685 & & & \\
\hline
\end{tabular}

Predictor: (constant), income tax

Dependent variable: Entrepreneurial Development

Source: Researchers' computation (2014)

Hypothesis two also depicts a significant relationship between interest rates and entrepreneurial development. The correlation related to wide margin between interest rate and entrepreneurial development in the states is positive (.526) and is statistically significant at (.000). With reference to the model summary table 3.3 below, it is observed that the coefficient of determination is 0.276 which means that about $27.6 \%$ of entrepreneurial development in the states is explained by interest rate, while other factors not under investigation accounted for about $72.9 \%$.

Table $3.3 \quad$ Model summary

\begin{tabular}{|l|l|l|l|l|}
\hline Model & R & R Square & Adjusted R Square & Std. Error of the Estimate \\
\hline 1 & $.526^{\mathrm{a}}$ & .276 & .271 & .709 \\
\hline
\end{tabular}

Predictor: (constant) interest rate

Source: Researchers' computation (2014)

Since the P value (.000) is less than the specified level of significance .05 , the null hypothesis is rejected and concludes that there is significant relationship between interest rates and entrepreneurial development in Lagos and Ogun states, Nigeria.

Table 3.4
\begin{tabular}{|ll|l|l|l|l|l|}
\hline Model & & Sum of Squares & Df & Mean Square & F & Sig. \\
\hline \multirow{4}{*}{1} & Regression & 134.678 & 5 & 26.936 & 53.539 & $.000^{\mathrm{b}}$ \\
& Residual & 352.677 & 701 & .503 & & \\
& Total & 487.355 & 706 & & & \\
\hline
\end{tabular}

Predictor: (constant), interest rate

Dependent variable: Entrepreneurial Development

Source: Researchers' computation (2014) 


\section{DISCUSSION, CONCLUSION AND RECOMMENDATIONS}

\section{Discussion of findings}

The test of the first hypothesis reveals that high profit entrepreneurs, who are prepared to borrow from banks, give consideration to lending rate and the existing government policy on interest rate. Similarly, interest rate differentials among banks provide clues as to whether funds are either attractive or repulsive. Prevailing interest rates among banks are generally used as decision-making consideration by entrepreneurs whose business requires huge funds (Adebayo, 2008). In a study designed to investigate the impact of interest rates and other macroeconomic factors on manufacturing performance in Nigeria, Adebiyi and Babatope-Obasa (2012), using co-integration and error correlation mechanism technique with annual time series, discovered that interest rate spread and government deficit financing have negative impact on growth of the Nigerian manufacturing subsector. The result thus confirmed a correlation between interest rate and manufacturing activities. However, findings from Adebiyi and Babatope-Obasa (2012) and from this study tend to justify an empirical position on the correlation between interest rate and entrepreneurial development in Nigeria. Further interpretation of the result implies that a high interest rate, which may arise from high interest rate, discourages entrepreneurial development. Hence, this consequently retards entrepreneurial development.

Furthermore, it is evident from this study that a major problem facing entrepreneurs is income taxes. Individual and entrepreneurs complained about the ripple effects associated with income taxes. This problem arises from the mismatch between fiscal responsibilities and fiscal powers or jurisdiction to assess and impose taxes. Some States take the initiative of imposing certain taxes, which has led to arbitrariness, harassment and even closure of businesses. One of the principles that guide both the imposition and design of tax is promotion of economic growth through entrepreneurial development. The negative impact arises from poor bureaucratic approach which has resulted in tax evasion by many entrepreneurs, particularly those who operate in the informal business sector in Nigeria. However; the results of this study revealed that the tax system in Nigeria is antientrepreneurial activities for it encompasses too many bureaucratic constraints for the entrepreneurs. The results revealed an evidence of lapses in the tax system which some entrepreneurs in the state exploit to avoid and evade tax payment. The results of the study revealed the presence of imposition of multiple taxes on entrepreneurs and bureaucratic corruption of tax officials in Lagos and Ogun States, Nigeria. These have resulted into high cost of doing business by entrepreneurs within Nigerian business environment.

\section{Conclusion and Recommendations}

Since the study is set in the macro-economic business environment in Nigeria, consistent results of the study suggests that interest rate policy should be meticulously formulated by the government's regulatory authority in the financial sub-sector of the economy. The combination of spending cuts and tax reduction should be considered as galvanized efforts for improved entrepreneurship activities in Nigeria. It is concluded that there should be a degree of uniformity in personal income tax imposition and a clear line of local levies that will not impinge on the running cost of entrepreneurial activities in Nigeria. Also, government should compel operators in the financial sector to implement policies that make credit available to all categories of entrepreneurs. This effort will promote entrepreneurship development significantly in the state since the study revealed a behavioural relationship between interest rate and entrepreneurial development. It is therefore, recommended that financial policies that are investment-friendly should be formulated and implemented to promote entrepreneurship in the states. Hence, Nigerian government should create an investor-conducive environment which encompasses stable macro-economic policies at the states level, since entrepreneurs may not be able to meet stringent conditions normally attached to loan facilities by mega banks. Micro finance outlets should be empowered by the state governments to reach out to cottage and small scale businesses in Nigeria.

\section{References}

[1] Adebayo, O. (2008). Bureaucratic practices in the age of information explosion: Role of government. Public Service Review No 6, 78

[2] Adebiyi, M.A., \&Babatope-Obasa, B. (2012). Institutional framework, interest rate policy and the financing of the Nigerian manufacturing sub-sector. Paper presentation, Economic Forum, Lagos, 5

[3] Ajayi, P.A. (2010). Poverty constraints and infrastructure: From the economic perspective,Journal of Sociological Studies, 5 (3), 108-123 
[4] Altshuler, R., \& Alan, J. A. (1990).The significance of tax law symmetries: An empirical investigation. Quarterly Journal of Economics 105(February):61-86.

[5] Anyanwu, C. (1998). Structural adjustment programmes financial deregulation and financial deepening in sub-Saharan African countries the Nigerian case. Nigerian Economic and Financial Review, 1(1): 1-23.

[6] Ashogbon, O.S., \&Ejike, I.M. (2008). Tax incentives; A stimuli for Nigerian entrepreneurship drive for economic development. Economic Review 10(3)

[7] Asikhia, O.U. (2009). Emotional response of small and medium scale business owners to micro finance banking in Nigeria. European Journal of Social Sciences, 11(4), $599-618$.

[8] Asikhia, O.U. (2013). Poverty alleviation, income redistribution and rural development in developing countries; Proceedings of 2013 International Conference on Poverty Alleviation, Income Redistribution and Rural Development in Developing Countries. School of Management and Business Studies, Lagos State Polytechnic, Ikorodu

[9] Audretsch, D., \&Keilbach, M. (2004). Entrepreneurship and regional growth: An evolutionary interpretation. Journal of Evolutionary Economics. 14(5): 605-16

[10] Audretsch, D.B., \&Thurik, A. R. (2000). 'What is new about the new economy: Sources of growth in the managed and entrepreneurship economics'.International Journal of Industrial Organization, 19(5): 795-821.

[11] Basile, P., John L.,\& Hugh, R. (2011). Money and interest rates in the United States during the Great Depression. In Geoffrey, W., Terence, C.M. \& Nicholas, C. (eds). Monetary and Banking History:Essays in honour of Forrest Capie, London: Routledge.

[12] Bello, M. (2012). Presentation of paper on "Sector Specific Incentives Policy for Nigeria; Manufacturing investments incentives" at the launching of the National Automative Council (NAC), Abuja, 10th April

[13] Bruce, D. (2000). Effects of the United States tax system on transitions into self-employment, Labour Economics, 7(5): 545-74.

[14] Chen, S., \&Ravallion, M. (2008). The developing world is poorer than we thought, but no less successful in the fight against poverty. Policy Research WorkingPaper 4703, Washington, DC: World Bank.

[15] Cullen, J., \& Gordon, R. (2007). Taxes and entrepreneurial risk-taking: Theory and evidence for the US. Journal of Public Economics, 91, 1479-1505.

[16] Dwivedi, D.N.(2007).Managerial Economics $6^{\text {th }}$ edition, New Delhi, Vikas Publishing House Ltd.

[17] Enahoro, J.A., \&Olabisi, J. (2012). Tax administration and revenue generation of Lagos State government, Nigeria, Research Journal of Finance and Accounting, 3(5):133-139.

[18] Enahoro, J.A., Olabisi, J., \&Dafe, P.O. (2013).Operational performance of fiscal and monetary policies in Nigerian financial institutions,Asian Economic and Financial Revenuer, 3(1):62-74.

[19] Feldman, D. C., \&Bolino, M.C. (2000). Career patterns of the self-employed: career motivations and career outcomes. Journal of Small Business Management.38 (3): 53-67

[20] Friedman, B., \&Kuttner, K. (1993). Economic activity and the short-term credit markets: An analysis of prices and quantities. Brooking Papers on Economic Activity. 2.

[21] Fritsch, M. (2008). 'How does new business formation affect regional development? Introduction to the special issue'. Small Business Economic, 30(1).

[22] Gboyega, O. (2013). Public policy and business growth in Nigeria,Journal of Public Policy Analysis, 3 (2)

[23] Gentry, W. M., \& Hubbard, R.G. (2004a). Tax policy and entry into entrepreneurship Mimeo, Williams College

[24] Gentry, W. M., \& Hubbard, R.G. (2000).Tax policy and entrepreneurial entry, America Economic Review 90 (2) 28387.

[25] Gentry, W. M., \& R. G. Hubbard (2005) 'Success taxes', entrepreneurial entry an innovation,” In: Jaffe, A. B., Josh Lerner and Scott Stern (eds.) Innovation Policy and the Economy - Volume 5, NBER and MIT Press.

[26] Gentry, W. M., \& Hubbard, R. G. (2004). The effects of progressive income taxation on job Turnover,Journal of Public Economics, 88, 2301- 2322

[27] Glover, C.N. (2012).Infrastructure and macroeconomic forces in Africa's development,Journal of Development Studies, 10 (3), 147-169

[28] Gordon, R. H. (2002). Can high personal tax rates encourage entrepreneurial activity? International Monetary Fund Staff Papers, 45

[29] Iyanda, O. (1988).The Business Institution and Environment in Nigeria, In Iyanda, O. \& Bello, J.A. (eds). Elements of Business in Nigeria,Akoka, University of Lagos Press, 2-7

[30] Kashyap, A., Stein J.C., \& Wilcox, D. (1993). Monetary policy and credit conditions Evidence from the composition of external finance. American Economic Review, 83, 78-98.

[31] Lehmann, E., Parmentier, A., \& Van der Linden, B. (2009).Optimal income taxation with endogenous participation and search unemployment, CREST working paper 2009-01.

[32] Melitz, R., \&Pardue, S. T. (1973). To conclude: Keep inflation low and, in principle, eliminate it Federal Reserve Bank of St. Louis Quarterly Review.

[33] Naudé, W.A. (2008). Entrepreneurship, developing countries, and development economics: new approaches and insights: Small Business Economics (in press) DOI 10.1007/s11187-009-9198-2.

[34] Okarfor, C., \&Mordi, C. (2010).Women entrepreneurship development in Nigeria: Effect of environmental factors. Petroleum - Gas University of Ploiesti Bulletin, 4 (LX11): 43 - 52.

[35] OkonjoIweala, N. (2013, September 2). Nigeria: Is interest rate another ghost haunting Nigeria? Vanguard 
[36] Okwu, A.T. (2012). Business environment and small and medium enterprises performance: Empirical evidence from Lagos state, Nigeria. PhD thesis, Department of Business and Marketing, Babcock University, Ilishan, Ogun State, Nigeria

[37] Osemeke, M. (2012). Entrepreneurial development and interventionist agencies in Nigeria, International Journal of Business and Social Sciences, 3(8); $255-265$

[38] Porter, M. E., \& Schwab, K. (2008).The Global Competitiveness Report 2008-2009. Geneva: World Economic Forum.

[39] Sokefun, A.O. (2012). Determinant of bank profitability: An assessment of the Nigerian banking sector. Ph.D. thesis, Department of Business and Marketing, Babcock University, Ilishan, Ogun State, Nigeria

[40] Slemrod, J. (2003).Small business and the tax system: Mimeograph, University of Michigan, February.

[41] Thurik, R. (2009). Entrepreneurship, economic growth and policy in emerging economics. World Institute for Development Economics Research.Research Paper No.2009/12. Helsinki: UNU-WIDER.

[42] Tily, G. (2010).Keynes betrayed: The General Theory, the Rate of Interest and 'Keynesian' Economics. Basingstoke: Palgrave Macmillan.

[43] Turner, P. (2011). Fiscal dominance and the long-term interest rate: Financial Markets Group, London School of Economics Special Paper No 199. March

[44] Ukpon, B. (2012). Tax-cost effect on business conduct in Lagos: Need for policy appraisal. African Journal of Cost Accounting Practices 5(2)

[45] World Bank (2006).Infrastructure at the crossroads: Lessons from 20 years of World Bank experience. Washington DC: The International Bank for Reconstruction and Development/ The World Bank. 